\title{
Description of sexuales of Sipha (Sipha) littoralis (Walker, 1848) (Aphididae: Chaitophorinae) with remarks on its distribution and host plants
}

\author{
Karina Wieczorek
}

Wieczorek, K. 2009: Description of sexuales of Sipha (Sipha) littoralis (Walker, 1848) (Aphididae: Chaitophorinae) with remarks on its distribution and host plants. - Entomol. Fennica 20: 100-104.

Oviparous female and male of Sipha (Sipha) littoralis (Walker, 1848) (Aphididae, Chaitophorinae: Siphini) are described and illustrated in detail. Notes on the distribution as well as a list of host plants is given.

K. Wieczorek, Department of Zoology, Faculty of Biology and Environmental Protection, University of Silesia, Bankowa 9, 40-007 Katowice, Poland; E-mail: karina.wieczorek@us.edu.pl

Received 4 March 2008, Accepted 25 March 2008

\section{Introduction}

Walker (1848) described Aphis littoralis from dry preserved viviparous apterous females, oviparous apterous females and apterous males and he wrote: "I have not observed yet any outwards difference between viviparous and oviparous form" and with reference to male: "it appears with the oviparous female at the end of October, but is comparatively scarce : the body is brown, and slightly increases in breadth from the head till near the tip of the abdomen : the feelers are about half the length of the body." The specimens of $A$. littoralis from the Dry Collection of Francis Walker have been mounted and the viviparous females redescripted by Laing (1921), who placed the species into the genus Sipha. The Dry Collection contained four apterous viviparous females and two larvae labelled littoralis Walker, an adult from the labelled series has been marked as a type; however, no specimens of males or oviparae have come to light (Doncaster 1961).Viviparous apterous females have been also redescripted by Theobald (1929), Stroyan (1977) and Heie (1982), but sexuales have never been described.

\section{Material and methods}

Material examined. From British Museum (Nat. Hist.) collection in London: United Kingdom, Wales, Convy, 30.X.1973, Festuca rubra, leg. R.N.B.P., 4 ovip., BM 1982 492; United Kingdom, Wales, Convy, 30.X.1973, F. rubra, leg. R.N.B.P., 3 males., BM 1982492.

From Laurentian Forestry Centre, Sainte-Foy Collection: Russia, Murmansk, 21.VIII.1993, marshy sea-shore with Juncus sp., sweepings, leg. Pzzhiboz, 3 ovip., 2 males.

External structures were examined using a light microscope Nikon Eclipse 600. Measurements are given in $\mathrm{mm}$ (Table 1 and 2).

\section{Descriptions}

Oviparous female (Fig. 1a). Coloration of live specimens: colour in life probably similar to apterous viviparous female: dark green, rarely pale green (Walker 1848); pigmentation when mounted: pale except for apices of antennae, tarsi and rostrum which are dusky. Body elongate, 
Table 1. Measurements of oviparous apterous females of Sipha (S.) littoralis (lengths in $\mathrm{mm}$ ).

\begin{tabular}{|c|c|c|c|c|c|c|c|}
\hline \multirow[t]{2}{*}{ No. } & \multirow[t]{2}{*}{ Body } & \multirow[t]{2}{*}{ Antenna } & \multicolumn{3}{|c|}{ Antennal segments } & \multirow{2}{*}{$\begin{array}{c}\text { Apical } \\
\text { segment } \\
\text { of rostrum }\end{array}$} & \multirow{2}{*}{$\begin{array}{l}\text { Hind } \\
\text { tarsus }\end{array}$} \\
\hline & & & III & IV & $\mathrm{Va}+\mathrm{Vb}$ & & \\
\hline 1 & 2.25 & 0.47 & 0.13 & 0.05 & $0.08+0.075$ & 0.1 & 0.14 \\
\hline 2 & 1.97 & 0.37 & 0.12 & 0.04 & $0.07+0.05$ & 0.09 & 0.13 \\
\hline 3 & 2.29 & 0.42 & 0.13 & 0.05 & $0.08+0.06$ & 0.1 & 0.15 \\
\hline 4 & 1.96 & 0.45 & 0.14 & 0.06 & $0.09+0.06$ & 0.07 & 0.15 \\
\hline 5 & 2.10 & 0.54 & 0.15 & 0.075 & $0.09+0.08$ & 0.08 & 0.13 \\
\hline
\end{tabular}

Table 2. Measurements of apterous males of Sipha (S.) littoralis (lengths in $\mathrm{mm}$ ).

\begin{tabular}{|c|c|c|c|c|c|c|c|}
\hline \multirow[t]{2}{*}{ No. } & \multirow[t]{2}{*}{ Body } & \multirow[t]{2}{*}{ Antenna } & \multicolumn{3}{|c|}{ Antennal segments } & \multirow{2}{*}{$\begin{array}{c}\text { Apical } \\
\text { segment } \\
\text { of rostrum }\end{array}$} & \multirow{2}{*}{$\begin{array}{l}\text { Hind } \\
\text { tarsus }\end{array}$} \\
\hline & & & III & IV & $\mathrm{Va}+\mathrm{Vb}$ & & \\
\hline 1 & 1.60 & 0.67 & 0.27 & 0.1 & $0.075+0.09$ & 0.1 & 0.15 \\
\hline 2 & 1.60 & 0.67 & 0.27 & 0.1 & $0.075+0.08$ & 0.1 & 0.15 \\
\hline 3 & 1.47 & 0.72 & 0.31 & 0.09 & $0.09+0.09$ & 0.07 & 0.12 \\
\hline 4 & 1.63 & 0.84 & 0.35 & 0.14 & $0.09+0.09$ & 0.08 & 0.14 \\
\hline
\end{tabular}

ovate, length $1.96-2.29 \mathrm{~mm}$ and width $0.75-0.95$ $\mathrm{mm}$. Head and prothorax not fused. Abdominal tergites sclerotized, partially fused, with distinct membranous intersegmental lines between segments I/II, VI/VII, VII/VIII. Sculpture very visible on head, thorax, abdomen, cauda and anal plate which are densely covered with rows of minute spinules. Dorsal chaetotaxy: dorsal hairs not numerous, on thorax and abdominal segments I-VI 0.02-0.035 mm long, on abdominal segments VII and VIII $0.05-0.075 \mathrm{~mm}$ long, spiny. Head chaetotaxy: near the frontal margin 4-6 frontal hairs, pointed, 0.05-0.06 mm long and 68 discal ones, shorter and spiny. Antennae (Fig. 1b) short, reaching just to prothorax, 5-segmented, 0.18-0.25 times the body length. Processus terminalis $(\mathrm{Vb})$ as long as base $(\mathrm{Va})$ or a bit shorter; other antennal ratios are: $\mathrm{Vb}:$ III 0.41-0.57; V : III 1.0-1.1; V : IV 2.2-3.0. Antennal chaetotaxy: segment I with 1 hair; segment II with 1 hair; segment III with 0-2 hairs; segment IV with $0-1$ hair opposite the small primary rhinarium; Va with $0-1$ hair and 2 small sensehairs at the tip of the processus terminalis; all of them very short; the longest antennal hair III about 0.5 times the basal articular diameter of this segment. Frons subconical. Eyes with distinct ocular tubercles. Rostrum short, reaching second coxae, with an apical segment (RAS) (Fig. 1c) blunt, short $0.07-0.1 \mathrm{~mm}$ long, 0.53-0.75 times III antennal segment and 0.46-0.70 times II segment of hind tarsus (II HT), with 2 secondary hairs. Legs short, hind tibiae (Fig. 1d) slightly thickened with 6-15 roundish or irregular shaped scent plates at the middle part of the tibiae; first tarsal segments with 5 hairs, empodial hairs pointed. Siphunculi placed on abdominal segment $\mathrm{V}$, short, conical, spinulose, $0.045 \mathrm{~mm}$ in basal diameter. Cauda $0.11 \mathrm{~mm}$ long, knobbed, with 3 pointed and $0.06-0.08 \mathrm{~mm}$ long hairs.

Apterous male (Fig. 2a). Coloration of live specimens: brown (Heie 1982); pigmentation when mounted: yellowish, antennae, legs, rostrum siphunculi, genitalia and dorsal sclerites dusky. Body elongate, slender; length 1.47-1.63 $\mathrm{mm}$ and width $0.55-0.60 \mathrm{~mm}$. Head, thorax and abdominal segment I free, abdominal segments II-VII fused. Sculpture very visible - body densely covered with rows of spinules $0.01 \mathrm{~mm}$ long. Abdominal segments I-IV with small marginal, pleural and spinal sclerites, segments VVII with small marginal sclerites and spinopleural plates (visible only in few specimens). Dorsal chaetotaxy: thorax and abdominal segments I-IV with spiny $0.03-0.045 \mathrm{~mm}$ long hairs, segments V-VIII with pointed $0.05-0.075 \mathrm{~mm}$ 


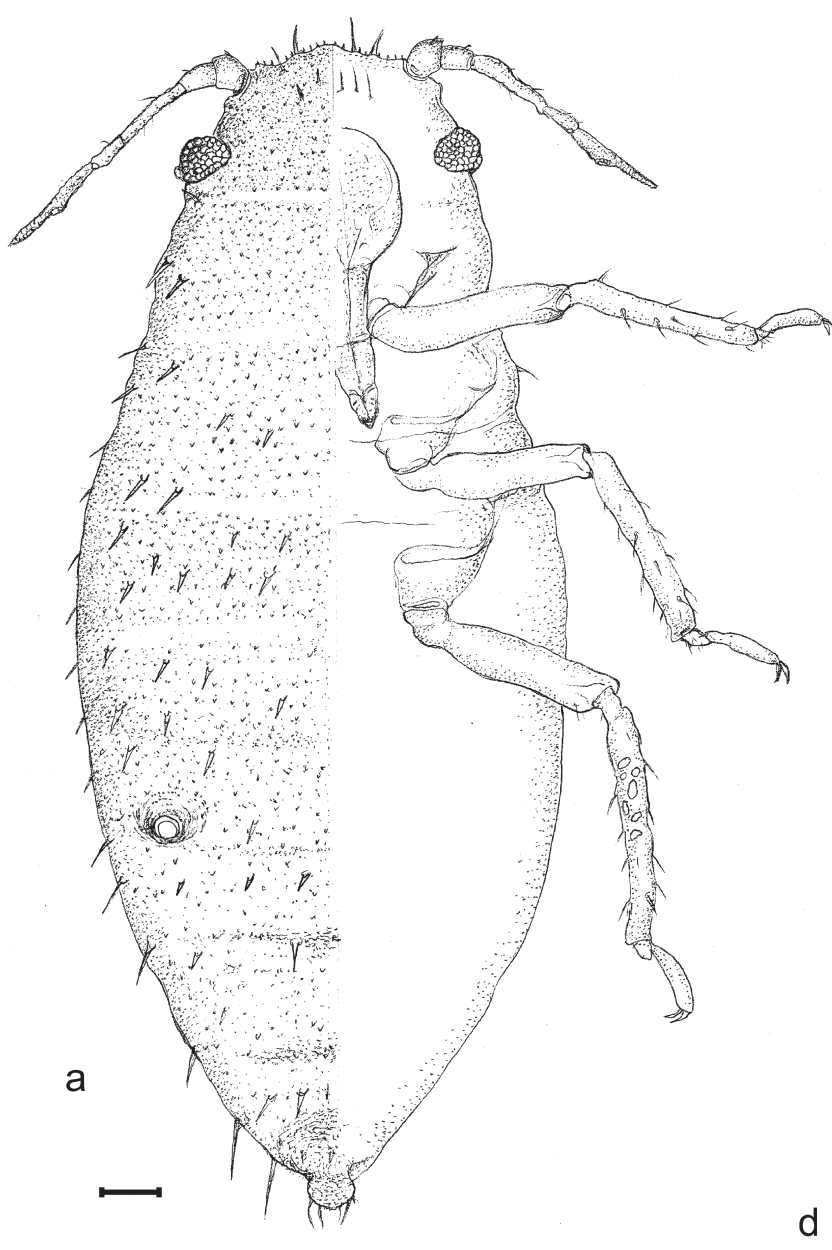

d

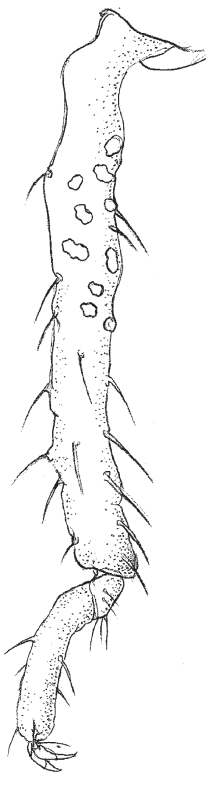

b

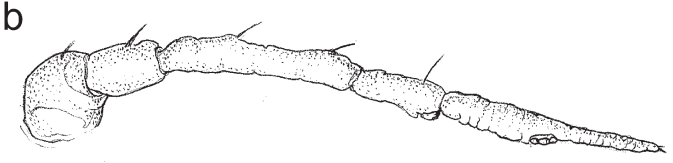

C

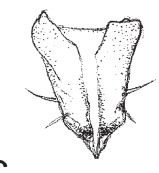

Fig. 1. Oviparous female of Sipha (S.) littoralis. - a. General feature. - b. Antenna. - c. Apical segment of rostrum. - d. Hind tibia and tarsus. Scale bars $0.1 \mathrm{~mm}$. long hairs. Head chaetotaxy: hairs pointed and 0.45-0.075 mm long. Antennae (Fig. 2b) long, reaching just to mesothorax, 5-segmented, 0.40.51 times the body length. Processus terminalis (Vb) 0.85-1.2 times Va, other antennal ratios are: Vb : III 0.25-0.32; V : III 0.54-0.61; V : IV 0.352.1. Antennal chaetotaxy: segment I with 1 hair; segment II with 1 hair; segment III with 3 hairs; segment IV with 0-1 hair opposite the small primary rhinarium; Va with 0-1 hair. Antennal hairs short, the longest antennal hair III as long as basal articular diameter of this segment. Segment III with 30-32, segment IV with 14-15 roundish secondary rhinaria. Frons subconical. Eyes with distinct ocular tubercles. Rostrum short, reaching second coxae with an apical segment (RAS) (Fig. 2c) blunt, short, 0.07-0.1 mm long, 0.22-0.37 times III antennal segment and $0.57-0.6$ times II segment of hind tarsus (II HT), with 2 secondary hairs. First tarsal segments with 5 hairs, empodial hairs pointed. Siphunculi placed on abdominal segment V, short, conical, spinulose. Cauda 0.06 mm long, knobbed. Genitalia (Fig. 2d) well developed, strongly sclerotised, dark. 


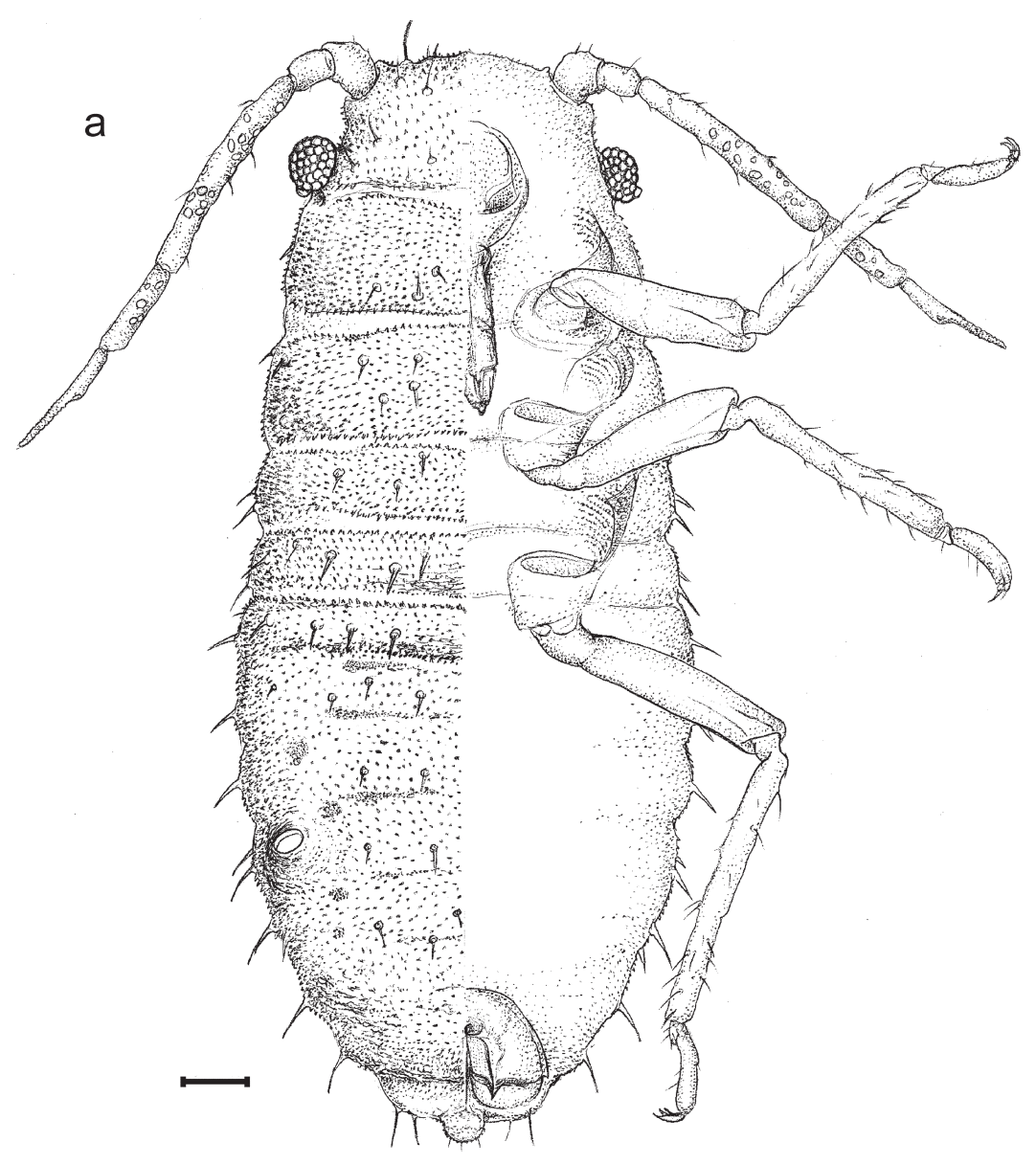

Fig. 2. Male of Sipha (S.) littoralis. - a. General feature. - b. Antenna. - c. Apical segment of rostrum. $-d$. Genitalia. Scale bars $0.1 \mathrm{~mm}$.

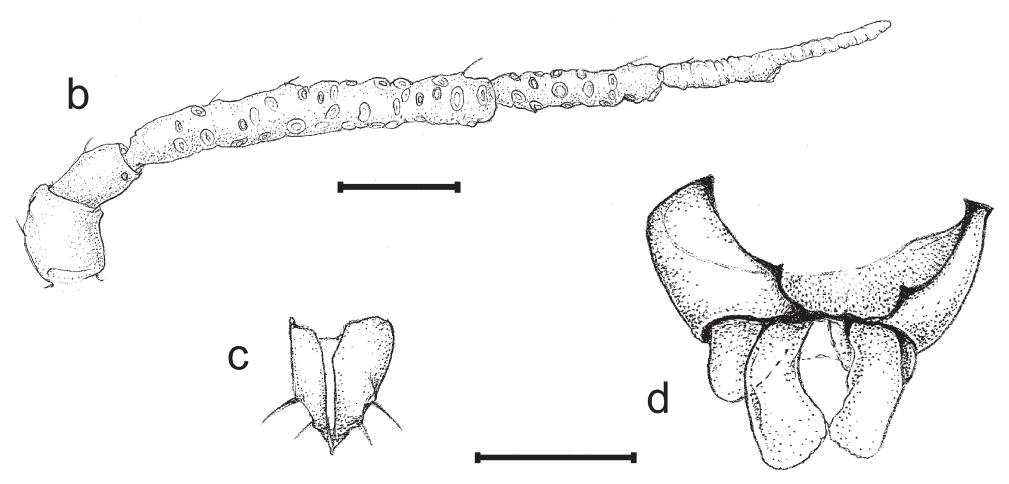

\section{Distribution and biology}

Geographical distribution (Fig. 3): Denmark (South Jutland-Højer, Heie 1982: 152); Germany (north-west Germany, Börner 1952: 54); Lithuania (Jurbarkas, Juronis 1984: 14); the Netherlands (Hille Ris Lambers 1939: 82); Russia (Murmansk, Laurentian Forestry Centre, Sainte-Foy
Collection:); Sweden (Norrbotten-Luleå, Brändön, Ossiannilsson 1969: 29); United Kingdom (near Lancaster, Locus Typicus, Walker 1848: 44-45; Laing 1921: 119-120, Theobald 1929: 7, Kloet\&Hincks 1964: 69, St. Cyrus, Stornoway, Nairn, Lochboisdale, South Uist, Inverness, Shaw 1964:72, Stroyan 1977:41, Wales, Convy, British Museum (Nat. Hist.) Collection). 


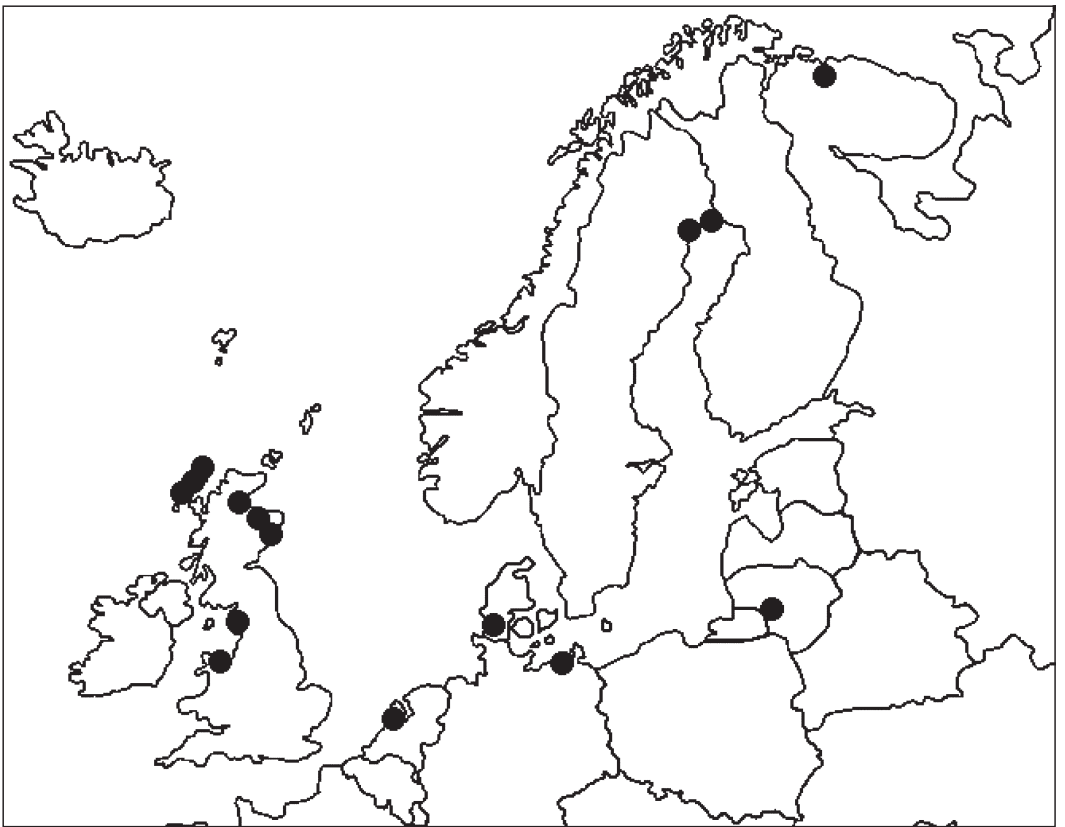

Fig. 3. Distribution of Sipha (S.) littoralis.
Host plants. Calamagrostis epigejos (L.) Roth, Festuca rubra L., Puccinellia maritima (Huds.) Parl., Spartina maritima (Curt.) Fern.

Life history. Halophilous species on coastal saltings, in Lithuania, however, has not been collected in its typical habitat (Juronis 1984), probably widely distributed in suitable localities but rarely recorded. The aphids live in the leaf sheaths (Heie 1982), alate viviparous females are very rare and have never been described; sexuales occur in October; in Russia, Murmansk, this generation has been collected also in August.

Acknowledgements. I would like to thank F.W Quednau (Laurentian Forestry Centre, Sainte-Foy, Quebec, Canada) and J. H. Martin (Museum of Natural History, London, Great Britain) for the opportunity to examine the material and £. Junkiert for drawings. I also want to thank Dr. Rimantas Rakauskas and an anonymous reviewer for useful comments which improved the manuscript.

\section{References}

Börner, C. 1952: Europae centralis Aphides (1), Die Blattläuse Mitteleuropas: Namen, Synonyme, Wirtspflanzen, Generationszyklen-Schriften der Thüringischen Landesanbeitsgemeinschaft für Helpflanzen kunde und Heilpflanzenbeschaffung in Weimar 4, (1). Mitteilungen Thüringishen der Botanischen Gesellschaft Beiheft 3: 1-488.
Doncaster, J. P. 1961: Francis Walker's Aphids. — British Museum (Natural History), London, 1-165.

Heie, O. E. 1982: The Aphidoidea (Hemiptera) of Fennoscandia and Denmark. II. The family Drepanosiphidae. - Fauna Entomologica Scandinavica, Klampenborg 11: 1-176.

Juronis, V.1984: 31 new to Lithuanian SSR aphid species found in 1981-1982. New and rare for the Lithuanian SSR insect species. Records and descriptions of 1984. Vilnius, pp. 13-18.

Kloet, G. S. \& Hincks, W. D. 1964: A Check List of British Insects. Second Edition (Revised). Small Orders and Hemiptera. Handbooks for the Identification of British Insects. (9)1, Royal Entomological Society of London, pp. 1-154.

Laing, F. 1921: On various genera of British Aphids. Entomologist's Monthly Magazine 57: 118-127.

Hille Ris Lambers, D. 1939: On some western European Aphids. - Zoologische Mededeelingen, Leiden 22: 81-120.

Ossiannilsson, F. 1969: Notes on some Swedish aphids (Hem.Aphidoidea). - Opuscula Entomologica 34 (1-2): 28-34.

Shaw, M. W. 1964: A basic list of the Scottish Aphididae. - Transactions of the Society for British Entomology 16(2): 49-92.

Stroyan, H. L. G. 1977: Homoptera: Aphidoidea (part.): Chaitophoridae and Callaphididae. - Handbooks for the Indentification of the British insects. - Royal Entomological Society of London, II, 4(a): 1-130.

Theobald, F. V. 1929: The Plant Lice or Aphididae of Great Britain, London, 3:364 pp.

Walker, F. 1948: Descriptions of Aphides. — The Annals and Magazine of Natural History (2), 2: 43-48. 